\title{
Insulin-Like Growth Factor-I Prevents Apoptosis in Neurons after Nerve Growth Factor Withdrawal
}

\author{
James W. Russell, ${ }^{1,2}$ Anthony J. Windebank, ${ }^{3}$ Angelo Schenone, ${ }^{4}$ Eva L. Feldman ${ }^{1}$ \\ ${ }^{1}$ Department of Neurology, University of Michigan, 200 Zina Pitcher Place, 4414 Kresge III, \\ Box 0588, Ann Arbor, Michigan 48109 \\ ${ }^{2}$ Veterans Administration Medical Center, Ann Arbor, Michigan 48109 \\ ${ }^{3}$ Molecular Neuroscience Program, Mayo Clinic and Foundation, Rochester, Minnesota 55905 \\ ${ }^{4}$ Department of Neurological Sciences and Rehabilitation, University of Genoa, Genoa, 16132 Italy
}

Received 15 January 1998; accepted 28 April 1998

\begin{abstract}
Insulin-like growth factor-I (IGFI) is emerging as an important growth factor able to modulate the programmed cell death $(\mathrm{PCD})$ pathway mediated by the cysteine-dependent aspartate proteases (caspases); however, little is known about the effect of IGF-I after nerve growth factor (NGF) withdrawal in neurons. To begin to understand the neuronal death-sparing effect of IGF-I under NGF-free conditions, we tested whether embryonic sensory dorsal root ganglion neurons (DRG) were able to survive in defined serum-free medium in the presence of IGFI. We further studied the role of IGF-I signaling and caspase inhibition after NGF withdrawal. NGF withdrawal produced histological changes of apoptosis including chromatin condensation, shrinkage of the perikaryon and nucleus, retention of the plasma membrane, and deletion of single cells. Both IGF-I and Boc-aspartyl (OMe)-fluoromethylketone (BAF), a
\end{abstract}

caspase inhibitor, equally reduced apoptosis after NGF withdrawal. The antiapoptotic effect of IGF-I was completely blocked by LY294002, an inhibitor of PI 3-kinase signaling, but not by the mitogen-activated protein (MAP) kinase/extracellular signal-regulated protein kinase (ERK) activated protein kinase inhibitor PD98059. Functional IGF-I receptors were extensively expressed both in rat and human DRG neurons, although they were most abundant in the neuronal growth cone. Collectively, these findings indicate that IGF-I, signaling though the PI-3 kinase pathway, is important in modulating PCD in cultured DRG neurons after NGF withdrawal, and IGF-I may be important in DRG embryogenesis. () 1998 John Wiley \& Sons, Inc. J Neurobiol 36: 455-467, 1998

Keywords: apoptosis; IGF-I; IGF-I receptor; neurons; NGF
Insulin-like growth factor-I (IGF-I) is a polypeptide essential for normal fetal, neonatal, and pubertal growth (Daughaday and Rotwein, 1989; Zackenfels et al., 1995). In vitro, IGF-I promotes the survival

\footnotetext{
Correspondence to: E. L. Feldman

Contract grant sponsor: Veterans Administration

Contract grant sponsor: NIH; Contract grant numbers: NS01938, NS14304, NS32843

Contract grant sponsor: Juvenile Diabetes Foundation

Contract grant sponsor: American Diabetes Foundation

(C) 1998 John Wiley \& Sons, Inc. CCC 0022-3034/98/040455-13
}

of cloned neural cell lines (Singleton et al., 1996a; Párrizas et al., 1997) and primary neurons (Zackenfels and Rohrer, 1993; Zackenfels et al., 1995; Miller et al., 1997; Sortino and Canonico, 1996). The biological actions of IGF-I are mediated by the type I IGF receptor (IGF-I receptor). Like IGF-I, there is developmental and tissue specific expression of the IGF-I receptor in the nervous system (Bondy et al., 1990; Lenoir and Honegger, 1983; van der Pal et al., 1988; Cohen et al., 1992).

In our laboratory, we are interested in the role 
of IGF-I and the IGF-I receptor in the growth, survival, and differentiation of neurons. Our preliminary studies suggest that IGF-I promotes neuronal survival by inhibiting programmed cell death (PCD) (Matthews and Feldman, 1996; Singleton et al., 1996a,b; Matthews et al., 1997). IGF-I rescues SH-SY5Y human neuroblastoma cells and primary dorsal root ganglia (DRG) neurons from stress induced PCD (Matthews and Feldman, 1996; Russell and Feldman, 1996) via IGF-I:IGF-I receptor activation of the phosphatidyl-inositol (PI) 3-kinase pathway (Singleton et al., 1996a; Miller et al., 1997). Upon PI 3-kinase activation, IGF-I signaling increases the levels of the antiapoptotic bcl proteins (Singleton et al., 1996a) while blocking activation of the effectors of neural death, the cysteine-dependent aspartate proteases (caspases) (Singleton et al., 1996a).

In the current study, we asked whether IGF-I could rescue DRG neurons from PCD induced by nerve growth factor (NGF) withdrawal. We chose the experimental paradigm of NGF withdrawal in cultured DRG neurons because it provides a model for looking at the role of trophic factors during development. Neurons in the vertebrate nervous system, like DRG, become dependent on neurotrophic factors once they begin to innervate their targets (Scott and Davies, 1990). In embryonic DRG there is an increase in PCD from embryonic day 15 onward as target factors including NGF determine the number of surviving sensory neurons (Coggeshall et al., 1994). These sensory neurons are acutely sensitive to growth factor withdrawal and insufficient NGF results in PCD (Deckwerth and Johnson, 1993; Scott and Davies, 1990). We used the paradigm of NGF withdrawal to determine what role IGF-I may play in DRG embryogenesis.

We report that both rat and human DRG express the IGF-I receptor. In vitro, IGF-I maintains DRG neuronal survival after NGF withdrawal for at least $72 \mathrm{~h}$. The antiapoptotic effect of IGF-I is mediated by PI 3-kinase and mimics the effect of caspase inhibitors such as Boc-aspartyl (OMe)-fluoromethylketone (BAF). Collectively, these results suggest a role for IGF-I and the IGF-I receptor in the development and maintenance of DRG neurons.

\section{MATERIALS AND METHODS}

\section{DRG Culture}

Dorsal root ganglion neurons from 15-day-old embryonic (E15) Sprague-Dawley rats (Harlan Sprague-Dawley,
Madison, WI) were aseptically plated on air-dried, collagen-coated plastic dishes as previously described (Windebank and Blexrud, 1986; Russell et al., 1994). Explants were incubated at $37^{\circ} \mathrm{C}$ with $5 \%$ carbon dioxide, in serumfree defined medium (SFDM) containing Eagle's minimal essential medium (EMEM; Gibco, Grand Island, NY) supplemented with $1.4 \mathrm{~m} M$ L-glutamine, $30 \mathrm{~m} M$ glucose, $30 \mathrm{n} M$ selenium, $10 \mathrm{n} M$ hydrocortisone, $10 \mathrm{n} M$ $\beta$-estriadiol, and $100 \mu \mathrm{g} / \mathrm{mL}$ transferrin (Sigma Chemical Co., St. Louis, MO). We had previously observed that this medium produces equal or superior neuronal growth and survival between 0 and $96 \mathrm{~h}$ compared to medium containing calf serum. Control DRG were supplemented with $10 \mathrm{ng} / \mathrm{mL} 2.5 \mathrm{~S}$ NGF (Bioproducts for Science, Madison, WI). We had previously obtained optimal DRG survival and neurite halo development in defined medium using this specific NGF product at this concentration (Russell and Feldman, 1996).

Dissociated DRG were prepared by incubating the whole DRG in $0.05 \%$ trypsin (Gibco) for $40 \mathrm{~min}$ at $37^{\circ} \mathrm{C}$, centrifuging at $800 \times g$ for $5 \mathrm{~min}$, followed by trypsin removal. The cells were washed in EMEM, followed by gentle tituration through a Pasteur pipet with a flamenarrowed tip. To reduce the number of contaminating Schwann cells and fibroblasts, neurons were preplated on positively charged Primaria plates (Falcon, Franklin Lakes, NJ) for $45 \mathrm{~min}$, which reduces the number of nonneuronal cells from $3 \%$ to $0.1 \%$ (Deckwerth and Johnson, 1994). The dissociated DRG neurons were plated at a density of approximately 5000 neurons/collagen-coated glass slide. To improve the quality of staining and counting, dissociated rat DRG cultures were used for all experiments except transmission electron microscopy (TEM). For TEM, whole DRG were used to improve the quality of embedding and sectioning of DRG neurons.

\section{Histological Determination of Apoptosis}

To determine the percentage of apoptotic cells, nuclear DNA fragments were tailed with digoxigenin-dUTP (Schmitz et al., 1991) and labeled with a fluorescein isothiocyanate (FITC) antibody as previously described (Gavrieli et al., 1993). Briefly, dissociated DRG on collagen-coated glass slides were fixed in $4 \%$ buffered formalin for $10 \mathrm{~min}$ at room temperature, washed in phosphatebuffered saline (PBS), and incubated with equilibration buffer, followed by freshly prepared terminal deoxynucleotidyl transferase (TdT) medium in a humid holding tray at $37^{\circ} \mathrm{C}$ for $1 \mathrm{~h}$. After stopping the reaction with stop/wash buffer, cells were stained with freshly prepared anti-digoxigenin fluorescein (Oncor, Gaithersburg, MD) diluted as per the manufacturer's instructions, for $45 \mathrm{~min}$ at room temperature. The cells were then counterstained with $1 \times$ freshly prepared propidium iodide for $15 \mathrm{~min}$ and mounted in Prolong (Molecular Probes, Eugene, OR) to preserve the immunofluorescent emission. Positive controls using DNA nicked with DNAse 1, and negative controls with water substituted for TdT were used for each experiment. 


\section{TEM}

For TEM, five to six whole DRG were cultured per dish, with a total of 30-40 DRG/condition. DRG were fixed in fresh Trump's fixative ( $1 \%$ glutaraldehyde and $4 \%$ formaldehyde in $0.1 \mathrm{M}$ phosphate buffer) for a minimum of $2 \mathrm{~h}$. Tissue was rinsed for $30 \mathrm{~min}$ in three changes of $0.15 M$ cacodylate buffer, $\mathrm{pH} 7.2$, followed by $1 \mathrm{~h}$ postfix in $1 \% \mathrm{OsO}_{4}$. After rinsing in three changes of distilled water for $30 \mathrm{~min}$, the tissue was en bloc stained with $2 \%$ uranyl acetate for $30 \mathrm{~min}$ at $60^{\circ} \mathrm{C}$. After en bloc staining, the tissue was rinsed once in distilled water, dehydrated in progressive concentrations of ethanol, washed in 100\% propylene oxide, and embedded in Spurr's resin. Thin (90-nm) sections were cut, placed on 200- $\mu$ m mesh copper grids, and stained with lead citrate. All chemicals were obtained from Electron Microscopy Services (Ft. Washington, PA). Photographs were taken with the operator unaware of the treatment condition, using a Phillips CM100 TEM operating at $60 \mathrm{kV}$. Images were stored digitally.

\section{Effect of NGF Withdrawal and IGF-I on Neuronal Apoptosis}

To initiate NGF withdrawal, one of two methods was used. In both methods, the cultures were preplated on Primaria plates to remove most of the contaminating primary Schwann cells and fibroblasts (Deckwerth and Johnson, 1994). First, at the time of plating, dissociated DRG neurons were cultured in SFDM alone without NGF, or with NGF, IGF-I, or a combination of the two. Second, DRG neurons after preplating were cultured in SFDM, $10 \mathrm{ng} / \mathrm{mL}$ NGF, and $40 \mu M$ 5-fluoro-2' deoxyuridine (FUDR)/uridine (Sigma) to ensure removal of virtually all Schwann cells and fibroblasts. Cultures were maintained in FUDR/uridine for 5 days. The neuron rich cultures were then washed three times in EMEM and incubated in SFDM without NGF, NGF and IGF-I, or IGF-I alone. In cultures in which NGF was excluded, anti-NGF antibody (Collaborative Biomedical Products, Bedford, MA) in a concentration of $10 \mu \mathrm{g} / \mathrm{mL}$ was added to bind traces of NGF remaining after washing. Test medium was changed every $24 \mathrm{~h}$. IGF-I used at a concentration of 1-100 $\mathrm{n} M$ was a gift from Cephalon (West Chester, PA). For composite data analysis, results were standardized against control conditions. To determine the percentage of apoptotic nuclei, neurons were cultured for $12-72 \mathrm{~h}$ in test media, photographed with a Leitz Orthoplan microscope, and counted by an observer blinded to the condition using a random-order number grid system as previously described (Russell et al., 1995). Approximately 5000 neurons were plated per slide, four slides were reviewed per condition, and experiments were repeated at least in triplicate. Only positively identified neuronal nuclei on corresponding phase contrast images were counted to exclude potential artifactual staining. DRG neurons have rounded, phase-bright cell bodies with clear neurite extensions. For electron microscopy, whole DRG were plated in test media for $48 \mathrm{~h}$ and then prepared for electron microscopy as described below. Apoptosis on TEM was not quantified; however, three thin sections separated vertically by at least $60 \mu \mathrm{m}$ (to avoid photographing the same nucleus twice) were studied from each of the blocks.

To determine if the neuroprotective effect of IGF-I in neuronal survival was mediated by activation of PI 3kinase or by mitogen-activated protein (MAP)-kinase signaling, we studied the effect of specific inhibitors on apoptosis. Dissociated DRG neurons were cultured as indicated above. Cultures were then incubated for $48 \mathrm{~h}$ in control medium, medium containing no NGF, with 100 $\mathrm{n} M$ IGF-I alone, with $100 \mathrm{n} M$ IGF-I and $10 \mu M$ PI 3kinase inhibitor (LY294002), or with $100 \mathrm{n} M$ IGF-I and $10 \mu M$ MAP-kinase/extracellular signal-regulated protein kinase (ERK) inhibitor (PD98059). Both LY294002 and PD98059 were obtained from Biomol (Plymouth Meeting, PA). Cells were preincubated for $1 \mathrm{~h}$ with LY294002 or PD98059, prior to addition of IGF-I.

To determine if inhibition of caspase activation would inhibit apoptosis induced by NGF withdrawal, we used Boc-aspartyl (OMe)-fluoromethylketone (BAF), which generally inhibits caspases including caspase-3. DRG neurons were cultured as indicated above and then incubated for $48 \mathrm{~h}$ in control medium, medium containing no NGF, with $100 \mathrm{n} M$ IGF-I alone, $100 \mu M$ BAF, or 100 $\mu M$ BAF with $100 \mathrm{n} M$ IGF-I. BAF was a gift from Dr. Brenda Shiver, Parke Davis, Ann Arbor, Michigan. Previous experiments in our laboratory indicated the optimal concentration of BAF for blocking PCD in DRG neurons was $100 \mu M$.

\section{Immunohistochemistry, In Situ Hybridization, and Reverse Transcriptase-Polymerase Chain Reaction (RT-PCR)}

Dissociated E15 rat DRG neurons were cultured for 24 $\mathrm{h}$ in SFDM with $40 \mu M$ FUDR (Sigma). After fixing in $4 \%$ paraformaldehyde and permeabilizing the neurons with Triton X-100 for $15 \mathrm{~min}$ each, they were incubated in $10 \mu \mathrm{g} / \mathrm{mL}$ of chicken IGF-IR immunoglobulin Y (IgY) polyclonal Ab (Upstate Biotechnology, Lake Placid, NY) for $6 \mathrm{~h}$, followed by $7.5 \mu \mathrm{g} / \mathrm{mL}$ of goat anti-chicken secondary antibody and $50 \mu \mathrm{g} / \mathrm{mL}$ avidin-fluorescein (Santa Cruz Biotechnology, Santa Cruz, CA), all at room temperature. The IGF-I receptor distribution was then visualized using a Noran Confocal Microscope, fitted with $\mathrm{Oz}$ with Intervision (Noran Instruments, Madison, WI).

Human DRG were obtained at autopsy between 8 and $12 \mathrm{~h}$ after death in patients in whom there was no evidence of neuropathy or of disorders predisposing to disease of the DRG. The bodies had been previously cooled within $1 \mathrm{~h}$ of death. For RT-PCR, total RNA was isolated from human adult autopsy DRG by a single-step method 
(RNA STAT-60; Tel-Test “B”); RNA was quantified by spectrophotometry at $260 \mathrm{~nm}$ and its integrity was tested by formaldehyde/agarose gel electrophoresis. First-strand cDNA was synthesized from $1 \mu \mathrm{g}$ total RNA in a $20-\mu \mathrm{L}$ reaction containing $5 \mathrm{mM} \mathrm{MgCl} 2,1 \times$ PCR buffer, $1 \mathrm{~m} M$ deoxyribonucleotide triphosphates, $2.5 \mu M$ random hexamers, $1 \mathrm{U} / \mu \mathrm{L}$ RNAse inhibitor, and $2.5 \mathrm{U} /$ $\mu \mathrm{L}$ Moloney murine leukemia virus reverse transcriptase (Gibco BRL Life Technologies, Gaithersburg, MD). PCR was performed in a $50-\mu \mathrm{L}$ reaction containing 10 $\mu \mathrm{L}$ of each of the mixtures from the RT reaction, $2 \mathrm{mM}$ $\mathrm{MgCl}_{2}, 1 \times$ PCR buffer, $0.6 \mathrm{~m} M$ dNTPs, $0.15 \mu M$ each of $5^{\prime}$ and $3^{\prime}$ primers, and $1.25 \mathrm{U} / 50 \mu \mathrm{L}$ of Native Taq DNA polymerase (Perkin-Elmer, Norwalk, CT). Amplification was performed for 30 cycles, each cycle consisting of $1 \mathrm{~min}$ denaturation at $95^{\circ} \mathrm{C}, 2 \mathrm{~min}$ annealing at $54^{\circ} \mathrm{C}$, and $3 \mathrm{~min}$ extension at $72^{\circ} \mathrm{C}$; an additional extension time of $7 \mathrm{~min}$ at $72^{\circ} \mathrm{C}$ was added at the end of the 30 cycles. Primers were identified using the Right Primer BioDisk Software (Biodisk, San Francisco, CA). IGF-I receptor sense and anti-sense primers ( $5^{\prime}$-GCCTTTCACATTGTACGCATC- 3 ' and 5'-CTCCCACTCATCAGGAACGTACAC-3') were selected from human cDNA sequences (GenBank accession no. M23102) (Ullrich et al., 1986). The respective rat primers were antisense: $5^{\prime}-$ GGCAGACGTCACAGAATCGATGGT-3' and sense: 5'-CATCCGCAACGACTATCAGCA-3' (GenBank accession no. M27293) (Werner et al., 1989). The PCR products were analyzed on a $2.0 \%$ agarose gel. The specificity of the obtained band was ascertained by cloning the PCR product (TA cloning kit; Invitrogen, San Diego, CA) and sequencing it with M13 forward and reverse universal primers, by the chain termination method (Sanger et al., 1977). Primers detecting $\beta$-actin mRNA (5'-CAATGCCAGGGTACATGGTGGTG-3' and 5'GGATCCGACTTCGAGCAAGAGATGGCCAC) were used to normalize for the amount of cDNA in each reaction.

After autopsy the human fifth lumbar DRG was removed and then embedded in paraffin as previously described (Dyck et al., 1986). For in situ hybridization, freshly cut sections were dewaxed in xylene, then ethanol, and then PBS. The tissue sections were immersed in 0.2 $M \mathrm{HCl}$ for $20 \mathrm{~min}$, washed in $0.1 \%$ diethylpyrocarbonate water ( DEPC $\mathrm{H}_{2} \mathrm{O}$ ), followed by PBS, and treated with $4 \mu \mathrm{g} / \mathrm{mL}$ proteinase $\mathrm{K}$ in a humid $50^{\circ} \mathrm{C}$ oven for $30 \mathrm{~min}$. The reactions were stopped by two washes of PBS/SSC, followed by fresh $0.1 \mathrm{M}$ triethanolamine and acetic anhydride. After further washing in SCC, the tissues were incubated in prehybridization buffer at $50^{\circ} \mathrm{C}$, and then hybridization performed in a humid $50^{\circ} \mathrm{C}$ oven using digoxigenin-labeled IGF-I receptor probes. Equal total concentrations of sense and antisense RNA probes were used on each tissue section. The digoxigenin-labeled human or rat IGF-I receptor RNA probes were prepared as outlined in the manufacturer's recommendations (Boehringer Mannheim, Mannheim, Germany) and as previously described (Leventhal et al., 1995; Werner et al.,
1989). The tissues were washed in SSC and a series of buffers (Boehringer Mannheim) as previously described (Viaene and Baert, 1995). Immunological detection of the IGF-I receptor was performed by incubation of the tissues with an antidigoxigenin antibody at $37^{\circ} \mathrm{C}$ for 30 min, rewashed, and incubated in a mixture of 4-Nitro blue tetrazolium chloride in buffer, 5-bromo-4-chloro-3indolylphosphate, and $125 \mathrm{n} M$ levamisole. After $3 \mathrm{~h}$, the color reaction was stopped in Tris- $\mathrm{HCl} /$ ethylenediaminetetraacetic acid (EDTA) buffer. Control sections were hybridized either without labeled probe, with digoxigenin-labeled antisense Neo RNA (Boehringer Mannheim), or with labeled sense probe.

\section{Statistical Analysis}

Assumptions about the Gaussian distribution of data were made using normalized cumulative frequency polygons and determination of the skewness and kurtosis of data. Data not exactly corresponding to a Gaussian distribution were analyzed using an appropriate mathematical transformation, usually $\log (x)$. Comparison of dependent variables was performed using factorial analysis of variance (ANOVA), and Fisher's LSD test was used as a posterior procedure for making pairwise comparisons of means. Inference was made using a probability $<.05$. For graphic and descriptive purposes, data are expressed in actual units \pm the standard error of the mean (S.E.M.).

\section{RESULTS}

\section{IGF-I Protects Neurons from Apoptosis after NGF Withdrawal}

When DRG neurons were cultured for 5 days in SFDM/FUDR and then NGF were withdrawn and $10 \mu \mathrm{g} / \mathrm{mL}$ NGF antibody was added (Fig. 1), there was an increase in the percentage of apoptotic neurons, ranging from $36.28 \pm 5.30 \%$ at $12 \mathrm{~h}$ to 99.70 $\pm 0.21 \%$ at $72 \mathrm{~h}$. By $48 \mathrm{~h}$, most of the DRG neurons were dead $(96.80 \pm 1.40 \%)$. The percentage of apoptotic neurons cultured in control SFDM containing $10 \mathrm{ng} / \mathrm{mL}$ NGF increased from 1.29 $\pm 0.61 \%$ at $12 \mathrm{~h}$ to $10.72 \pm 3.15 \%$ at $72 \mathrm{~h}$. In contrast, the percentage of apoptotic neurons after NGF withdrawal, but in the presence of IGF-I (Fig. 1 ), was essentially unchanged or slightly reduced after $72 \mathrm{~h}$. At $72 \mathrm{~h}$, the percentage of apoptotic neurons was $5.10 \pm 0.95$ for $1 \mathrm{n} M$ IGF-I and 1.93 \pm 0.73 for $100 \mathrm{n} M$ IGF-I. At all time periods including $72 \mathrm{~h}$, the percentage of apoptotic neurons in the presence of IGF-I alone was dose dependent. At 12 $\mathrm{h}$, the percentage of apoptotic neurons in control medium containing NGF was $8 \%$ less than with $1 \mathrm{n} M$ IGF-I alone (Fig. 1), and was significantly 


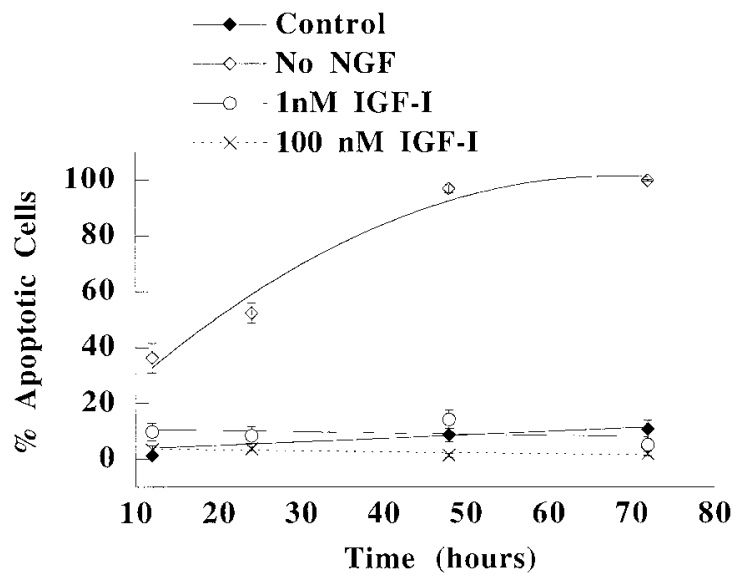

Figure 1 IGF-I prevents apoptosis in rat DRG neurons after NGF withdrawal. DRG neurons were cultured up to $72 \mathrm{~h}$ in SFDM containing $10 \mathrm{ng} / \mathrm{mL}$ NGF (control), no NGF with $10 \mu \mathrm{g} / \mathrm{mL}$ anti-NGF $\mathrm{Ab}$, and 1-100 n $M$ IGF with $10 \mu \mathrm{g} / \mathrm{mL}$ anti-NGF Ab. After NGF withdrawal, the percentage of apoptotic neurons increased up to $72 \mathrm{~h}$, with most of the neurons dying by $48 \mathrm{~h}$. In the presence of $100 \mathrm{n} M$ IGF-I, $<5 \%$ apoptotic neurons were seen at $72 \mathrm{~h}$, less than in control neurons with NGF ( $p$ $<.05)$. Neuronal survival in the presence of IGF-I alone, even at low concentrations $(1 \mathrm{n} M)$, at $12-72 \mathrm{~h}$ was statistically different from neurons in which NGF was withdrawn $(p<.001)$.

different from $1 \mathrm{n} M$ IGF-I $(p<.05)$. However, at $12 \mathrm{~h}$, there was no difference in the percentage of apoptotic cells in control medium containing NGF compared to medium containing 10 or $100 \mathrm{n} M$ IGF$\mathrm{I}$, although there was a significant difference between 1 and 10 or $100 \mathrm{n} M$ IGF-I $(p<.05)$. In contrast, by $24 \mathrm{~h}$, there was no statistical difference between the percent apoptotic neurons with control medium containing NGF and medium containing 1 $\mathrm{n} M$ IGF-I (Fig. 1).

When combined NGF/IGF-I and IGF-I alone were compared, we found that at $12 \mathrm{~h}$ there was $0.81 \pm 0.29 \%$ apoptotic neurons with $10 \mathrm{ng} / \mathrm{mL}$ NGF and $1 \mathrm{n} M$ IGF-I compared to $9.83 \pm 3.08 \%$ with $1 \mathrm{n} M$ IGF-I alone. However by $24 \mathrm{~h}$, combined NGF and $1 \mathrm{n} M$ IGF-I, or NGF and $\geq 10 \mathrm{n} M$ IGFI at any time point (data not shown) did not further significantly decrease the percentage of apoptotic neurons, suggesting that the antiapoptotic effects of NGF and IGF-I are not additive.

Dorsal root ganglion neurons were cultured in SFDM/FUDR as above, NGF were withdrawn, $10 \mu \mathrm{g} / \mathrm{mL}$ NGF antibody was added, and then test medium was added for $48 \mathrm{~h}$ (Fig. 2). Under these conditions, we found that most NGF deprived
DRG neurons had undergone apoptosis [Fig. 2(A) ]. IGF-I inhibited apoptosis after NGF withdrawal in a dose-dependent fashion in that the percentage of apoptotic neurons decreased from $14 \%$ with $1 \mathrm{n} M$ IGF-I to $7.6 \%$ with $10 \mathrm{n} M$ IGFI, and $1.4 \%$ with $100 \mathrm{n} M$ IGF-I [Fig. 2(B)]. The percentage of apoptotic neurons was significantly different with $1 \mathrm{n} M$ IGF-I alone compared to 10 $\mathrm{n} M$ IGF-I alone $(p<.01)$ and $100 \mathrm{n} M$ IGF-I $(p$

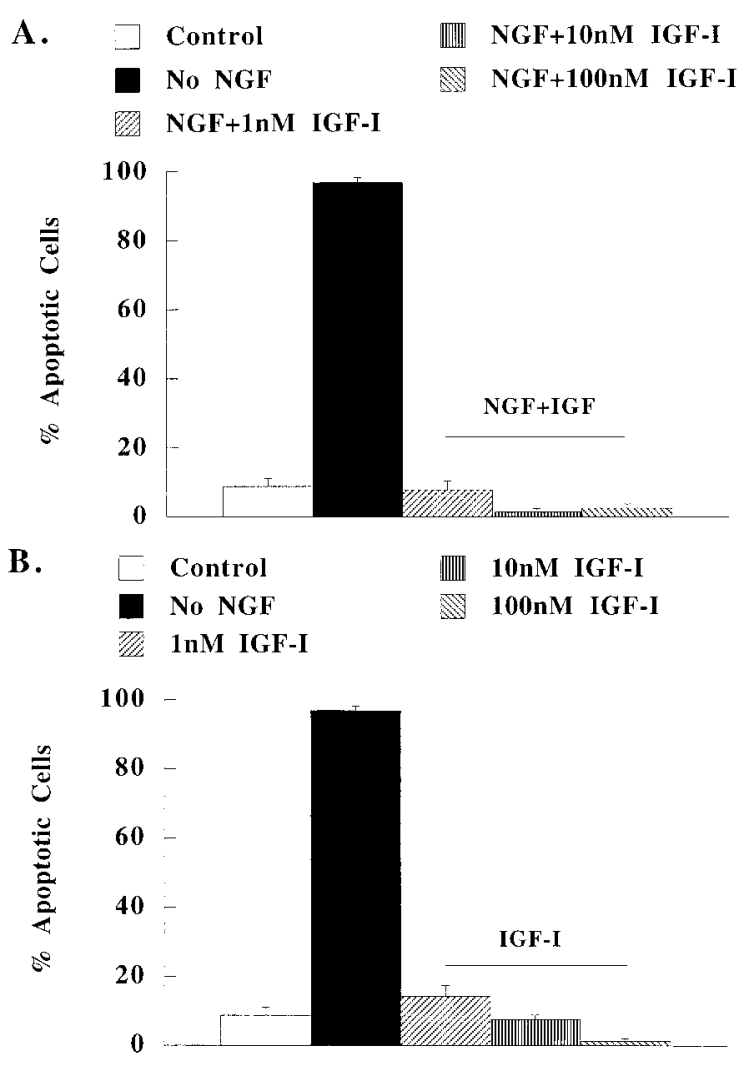

Figure 2 IGF-I prevents apoptosis of rat DRG neurons after NGF withdrawal at $48 \mathrm{~h}$. (A) DRG neurons were cultured for $48 \mathrm{~h}$ in SFDM with $10 \mathrm{ng} / \mathrm{mL} \mathrm{NGF}$, without NGF, and with NGF and 1-100 nM IGF-I combined. (B) DRG neurons cultured as above with 1-100 $\mathrm{n} M$ IGF-I alone. Condition 1 and 2 are the same in (A) and (B). In the absence of NGF, $>95 \%$ of neurons were dead at $48 \mathrm{~h}$. The percentage of apoptotic neurons was reduced by the addition of $1 \mathrm{n} M$ IGF-I to $14 \%$ ( $p<.0001$ ), and the number of apoptotic neurons was further reduced in a dose-dependent manner to $7.6 \%$ with $10 \mathrm{n} M$ IGF-I, and $1.4 \%$ with $100 \mathrm{n} M$ IGF-I. Although there was a slight decrease in the percentage of apoptotic neurons when NGF was combined with IGF-I, there was no statistical significance between neurons treated with IGF-I alone compared to NGF and IGF-I. The values are representative of the mean of three separate experiments, standardized against control values. 
$<.01)$, consistent with a dose-dependent increase in IGF-I neuroprotection against apoptosis after NGF withdrawal. In the presence of $100 \mathrm{n} M$ IGFI alone [Fig. 2(B)], the percentage of apoptotic neurons was significantly less than in control medium with NGF $(p<.05)$.

In a separate set of experiments, NGF was withdrawn or IGF-I added from culture day 1 instead of culture day 6 . No anti-NGF antibody was used in these experiments, but cultures were preplated to remove contaminating Schwann cells and fibroblasts. In these shorter-term experiments, at $48 \mathrm{~h}$ the percentage of apoptosis in control neurons $(15.85 \pm 5.33 \%)$ was slightly higher than longer-term cultures, but $100 \mathrm{n} M$ IGF-I alone with no NGF still reduced the percentage of apoptosis to $6.77 \pm 2.90 \%$. As with the longerterm cultures described above, IGF-I was neuroprotective in a dose-dependent manner after NGF withdrawal, and there was no additive effect with NGF and IGF-I combined (data not shown). Thus, although apoptosis was greater in controls in the first 2 days in culture compared to that after 1 week in culture, the neuroprotective effect of IGF-I was similar.

The classical changes of apoptosis were observed in DRG neurons after NGF withdrawal. Neurons were cultured in SFDM/FUDR for $48 \mathrm{~h}$ after preplating, and then test medium was added for $48 \mathrm{~h}$. Anti-NGF antibody $(10 \mu \mathrm{g} / \mathrm{mL})$ was added in addition to NGF withdrawal. Condensation of the nuclear chromatin into apoptotic bodies, and shrinkage of the nucleus and cytoplasm, but preservation of the cytoplasmic membrane were observed. At $48 \mathrm{~h}$, almost all neurons showed evidence of apoptosis, and there was single deletion of DRG neurons with preservation of surrounding satellite cells and Schwann cells [Fig. 3(B)]. With IGF-I alone [Fig. 3(C,D)], there was sparing of neurons. Although with $1 \mathrm{n} M$ IGF-I the neuronal nucleus [Fig. 3(C)] showed normal chromatin distribution, there was evidence of minimal perikaryeal shrinkage. With low-dose IGF-I, some of the neurons continued to classical changes of apoptosis, whereas with high-dose IGF-I (100 n $M$ ), most of the DRG neurons were morphologically normal with TEM. With combined NGF and IGF-I [Fig. 3(E,F)], both DRG neurons and satellite cells were morphologically normal. With NGF and $1 \mathrm{n} M$ IGF-I, neuronal perikarya were less likely to show early apoptotic changes compared to $1 \mathrm{n} M$ IGF-I alone, but no difference was seen with $100 \mathrm{n} M$ IGF-I compared to NGF and $100 \mathrm{n} M$ IGF-I.
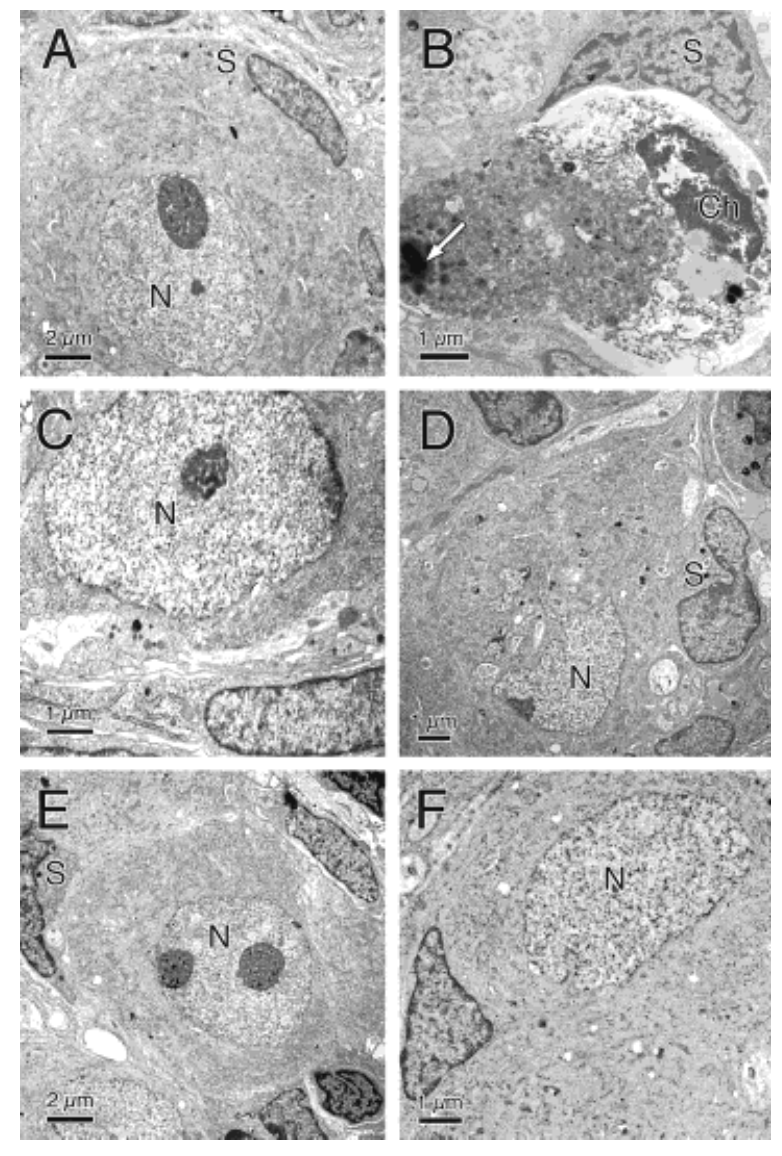

Figure 3 TEM of in vitro rat DRG at $48 \mathrm{~h}$ showing neuronal rescue by IGF-I in the absence of NGF. (A) Control DRG with $10 \mathrm{ng} / \mathrm{mL}$ NGF showing normal chromatin staining in the nucleus $(\mathrm{N})$, and an intact perikaryon. The neuroblast was encased in satellite cells (S). (B) DRG after $48 \mathrm{~h}$ NGF withdrawal. There was severe chromatin clumping $(\mathrm{Ch})$ observed in the nucleus, shrinkage of the perikaryon - although at higher magnification the plasma membrane remained intact - and single deletion of cells. At $48 \mathrm{~h}$, most of the neuroblasts were apoptotic. There was also a prominent collection of lipofusion (white arrow) commonly observed in apoptotic DRG neurons. The satellite cells ( $S$ ) were histologically unaffected by the NGF withdrawal. (C) DRG with $1 \mathrm{n} M$ IGF-I, but no NGF. The presence of IGF-I supported neuronal survival as indicated, although several neuroblasts continued to undergo apoptosis at this low concentration of IGF-I. (D) DRG with $100 \mathrm{n} M$ IGF-I. There was survival of most of the neuroblasts, with normal chromatin distribution in the nucleus $(\mathrm{N})$. The normal neuronal perikaryon was surrounded by satellite cells (S). (E) DRG with $1 \mathrm{n} M$ IGF-I and $10 \mathrm{ng} / \mathrm{mL}$ NGF. (F) DRG with $100 \mathrm{n} M$ IGF-I and $10 \mathrm{ng} / \mathrm{mL}$ NGF. In both $(\mathrm{E})$ and $(\mathrm{F})$, the neuronal nuclei $(\mathrm{N})$ were normal. Apoptotic neurons were rare in the presence of both NGF and IGF-I, and survival was slightly greater than controls at higher concentrations of IGF-I. 
Table 1 IGF-I and Neuronal Cell Death

\begin{tabular}{lcclrr}
\hline \multicolumn{1}{c}{ Condition } & \% Apoptosis & S.E.M. & \multicolumn{1}{c}{ Condition } & \% Apoptosis & S.E.M. \\
\hline NGF 10 ng/mL & 8.82 & 3.50 & LY294002 + IGF-I & 99.20 & 0.25 \\
No NGF & 95.40 & 2.40 & PD98059 + IGF-I & 3.40 & 0.58 \\
IGF-I 100 nM & 0.22 & 0.11 & BAF & 0.34 & 0.19 \\
& & & BAF + IGF-I & 0.38 & 0.35 \\
\hline
\end{tabular}

NGF: nerve growth factor; IGF-I: insulin-like growth factor I; LY294002: PI 3-kinase inhibitor; PD98059: MAP kinase inhibitor; BAF: Boc-aspartyl (OMe)-fluoromethylketone, a caspase inhibitor; S.E.M.: standard error of the mean.

\section{IGF-I Prevents Neuronal Apoptosis after NGF Withdrawal by Activation of PI 3-Kinase Signaling}

The neuroprotective effect of IGF-I after NGF withdrawal was blocked by $10 \mu M$ LY294002, an inhibitor of PI 3-kinase (Table 1). Since LY294002 will also potentially block NGF-induced PI 3-kinase signaling, we examined whether LY294002 would block PI-3 kinase signaling induced specifically by IGF-I alone. In the presence of $100 \mathrm{n} M$ IGF-I alone, most neurons survived NGF withdrawal at $48 \mathrm{~h}$. However with $10 \mu M$ LY294002 and $100 \mathrm{n} M$ IGFI, 99\% of neurons were dead at $48 \mathrm{~h}(p<.0001)$. In the presence of $10 \mu M$ PD98059, an inhibitor of MAP-kinase/MEK signaling, $100 \mathrm{n} M$ IGF-I still reduced the percentage of apoptotic neurons to below control levels $(p<.05)$, although IGF-I and PD98059 were slightly less neuroprotective than IGF-I alone (not statistically significant). Similar results were obtained whether or not anti-NGF antibody was present in test medium. We had previously shown in neurons that concentrations of PD98059 $>10 \mu \mathrm{m}$ had no appreciable additive effect in blocking the dual-specificity protein kinase MEK (Kim et al., 1997), and in preliminary data did not further block MAP kinase signaling in DRG neurons.

\section{Inhibition of the Caspase PCD Pathways Inhibits Apoptosis Induced by NGF Withdrawal}

Inhibition of caspase cleavage by BAF (100 $\mu M)$ almost completely blocked apoptosis induced by NGF withdrawal at 24 and $48 \mathrm{~h}$. When DRG neurons were cultured for 5 days in NGF, BAF was added, NGF was withdrawn and $10 \mu \mathrm{g} / \mathrm{mL}$ antiNGF antibody was added, the percentage of apoptotic neurons was $0.34 \pm 0.19 \%$ compared to 8.82 $\pm 3.50 \%$ control neurons $(p<.05)$. The percentage of apoptotic neurons could not be further decreased by the addition of $100 \mathrm{n} M$ IGF-I to $100 \mu M \mathrm{BAF}$, and results were not statistically significantly differ- ent from IGF-I alone or BAF alone. Apoptosis was less completely blocked by $10 \mu M$ BAF (data not shown).

\section{IGF-I Receptor Distribution in Rat and Human DRG}

Dorsal root ganglion neurons were found to express functional IGF-I receptor during development (E15 rat) and also in the adult human using both RTPCR and in situ hybridization techniques (Figs. 4 and 5). The sizes of the PCR products for human and rat IGF-I receptor were, respectively, 600 and 933 bp. Specificity was confirmed by sequencing the PCR products and finding 98\% homology with predicted sequences (Werner et al., 1989; Ullrich et al., 1986). Using immunohistochemistry with antibody specific for the IGF-I receptor, we demonstrated that the IGF-I receptor was abundantly distributed throughout the DRG neuron [Fig. 5(A)]. With confocal microscopy and z-series resolution of the three-dimensional structure of the neuron, we

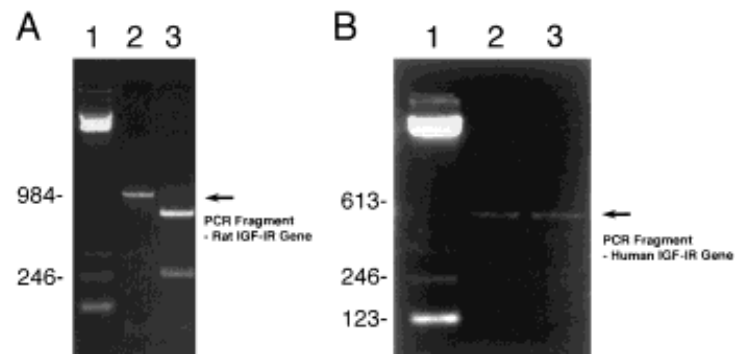

Figure 4 RT-PCR analysis of RNA transcripts using primers from IGF-I receptor in E15 embryonic rat DRG neurons (A) and human DRG neurons (B). (A) Rat DRG: Lane 1 contains a 123-base pair (bp) DNA ladder, and lane 2, an RT-PCR product from IGF-I receptor mRNA; lane 3, a Banl digest of lane 2 product yielding predicted 246- and 684-bp products. (B) Human DRG: Lane 1 contains a 123-bp DNA ladder; a 600-bp RTPCR fragment from adult human mRNA is seen in lanes 2 and 3 (two separate samples). Equal levels of $\beta$-actin were identified in each of the RT-PCR samples. 

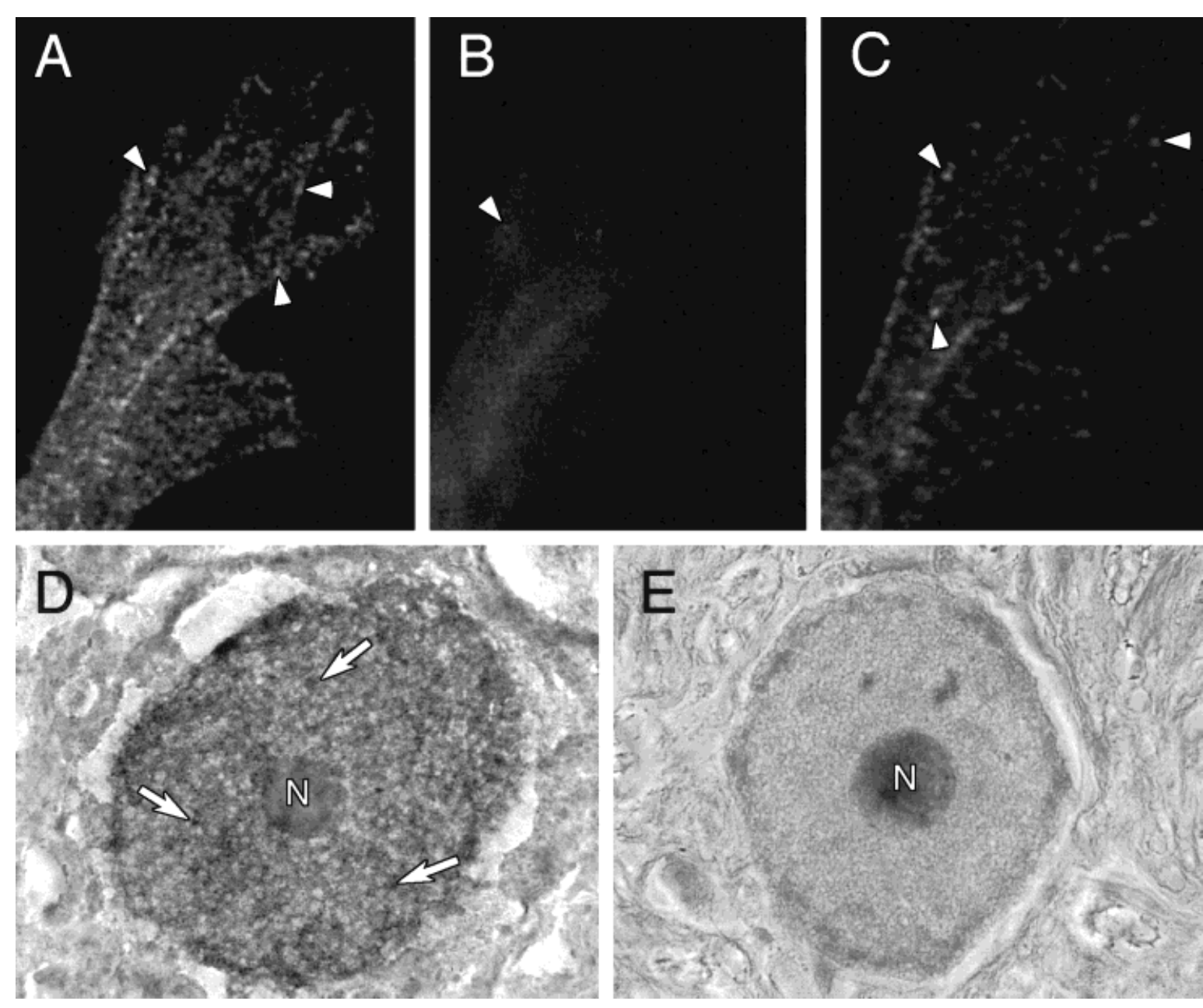

Figure 5 IGF-I receptor expression in the rat DRG neurite growth cone and in human DRG. (A) The IGF-I receptor (white arrows) was abundant in the rat neurite growth cone. Rat DRG were incubated with chicken IGF-IR IgY and viewed using confocal microscopy $(\times 1500)$. The figure represents a $\mathrm{z}$-series reconstruction of several image planes from the upper to the lower surface of the neurite growth cone. The IGF-I receptor was distributed throughout the neuron, but was most abundant in the DRG growth cone. (B) Image from an upper plane from the $\mathrm{Z}$-series described in (A). The image plane was adjusted to lie just below the upper surface of the neuron. Although the outline of the growth cone is seen, there are few IGF-I receptors present. (C) Image from a lower plane (adjacent to the ECM) of the z-series described in (A). More numerous IGF-I receptor staining (white arrows) is observed throughout the growth cone. (D) In situ hybridization for IGF-I receptor in human DRG using antisense probe showing abundant punctate labeling of IGF-I receptor mRNA (white arrows) throughout the neuronal perikaryon $(\times 500)$. $\mathrm{N}=$ DRG neuronal nucleus. There was less abundant labeling of satellite cells and fibroblasts. (E) Sense control showing no labeling of the neuron or supporting cells $(\times 500) . \mathrm{N}=$ DRG neuronal nucleus. Equal total concentrations of sense and antisense RNA probes were used on each tissue section.

found that the IGF-I receptor was mainly distributed near the surface of the neuron, was more abundant in the region of the neurite growth cone, and extended out to the outer edges of the developing lamellipodia [Fig. 5(A)]. Using z-series reconstruction, the receptor distribution was greater on the surface of the neuron in contact with the extracellular matrix (ECM), although the IGF-I receptor could be demonstrated throughout the neuron.

In human DRG, in situ hybridization using specific RNA probes to human IGF-I receptor mRNA developed with antidigoxigenin antibody showed 
abundant signal throughout the neuronal cytoplasm and was not localized to a specific region of the perikaryon [Fig. 5(B)]. The signal was likely specific as indicated by the absence of signal to labeled sense RNA probes [Fig. 5(C)]. In rat DRG, IGFI receptor mRNA was similarly widely distributed throughout the neuronal perikaryon (data not shown). In adult human DRG, IGF-I receptor mRNA was less abundant in satellite cells and fibroblasts.

\section{DISCUSSION}

In this study, we examined the ability of IGF-I to prevent apoptosis in DRG neurons after NGF withdrawal. Apoptosis refers to the characteristic morphological changes observed in PCD, including deletion of single cells, cell shrinkage, membrane blebbing, and compaction of chromatin (Kerr et al., 1972; Majno and Joris, 1995; Raff, 1992). Similar to sympathetic neurons, when NGF was withdrawn from DRG, the majority of neurons were committed to die by $24 \mathrm{~h}$ (Deckwerth and Johnson, 1993; Edwards and Tolkovsky, 1994) and apoptosis was the predominant form of cell death (Edwards and Tolkovsky, 1994). Using TEM, we observed prominent chromatin condensation of DRG neuronal nuclei, shrinkage of the perikaryon, and retention of plasma membrane. In addition, many of the apoptotic DRG had more prominent accumulations of lipofuscin granules in the cytoplasm than control neurons, a change that has been associated with aging and degeneration of neurons (Kerezoudi et al., 1995; Sasaki et al., 1997).

Insulin-like growth factor-I prevented apoptosis in DRG sensory neurons for at least $72 \mathrm{~h}$ after NGF withdrawal. In the presence of high concentrations of IGF-I, most of the DRG neurons had a normal histological appearance on TEM, and even small concentrations of IGF-I ( $1 \mathrm{n} M)$ maintained viability of neurons in the absence of NGF. We also used TdT-mediated dUTP-biotin nick end labeling (TUNEL) to quantitate the number of apoptotic neurons. In these experiments, we took advantage of the fact that in our culture system we can study a nearly pure neuronal population. Under these conditions, the calculated percentage of apoptotic neurons corresponded with the histological findings on TEM. IGF-I alone maintained neuron viability in the absence of NGF for periods of at least $72 \mathrm{~h}$. Furthermore, although neuron survival was improved slightly by combining low-dose IGF-I with NGF, at higher concentrations of IGF-I concomitant NGF had no additional antiapoptotic effect, suggesting that NGF and IGF-I do not necessarily act additively in inhibiting PCD. When IGF-I is used in vitro, as with neurotrophic factors such as NGF (Russell et al., 1994), the concentration of IGF-I required to promote a maximum biological effect is often greatly in excess of the receptor dissociation constant for that factor. Although an almost maximal antiapoptotic response was seen with $10 \mathrm{n} M$ IGFI, a small additive effect was achieved with 100 $\mathrm{n} M$ IGF-I. These observations may relate to IGFbinding proteins (IGFBPs) modulation of IGF-I binding at the IGF-I receptor (see Jones and Clemmons, 1995, for review), uptake and internalization of IGF-I by the IGF-I receptor, or proteolysis of IGF-I within the culture system.

Nerve growth factor withdrawal has been well described as a model for PCD in sympathetic neurons (see Deshmukh and Johnson, 1997, for review), as well as early differentiating cerebellar granule neurons (Muller et al., 1997), developing basal forebrain cholinergic neurons (Kew and Sofroniew, 1997), and differentiated PC12 cells (Tong et al., 1997). Recently, it has been shown that inhibition of trk A receptor tyrosine signaling does not affect apoptosis occurring in axotomized mouse DRG and nerve stumps. Furthermore, addition of NGF did not reduce the percentage of apoptotic neurons (Edstrom et al., 1997). This suggests that NGF may have a more circumscribed role in preventing PCD in DRG than initially proposed (Lindsay, 1988), whereas other growth factors like IGF-I may be important. In parallel with the current studies, we (Matthews and Feldman, 1996; Russell et al., 1996; Singleton et al., 1996a) and others (Miller et al., 1997) also found that IGF-I prevents PCD owing to a variety of neurotoxic stimuli in both transformed and primary neural cell lines.

Signaling through the PI 3-kinase pathway is important in the prevention of apoptosis by NGF (Yao and Cooper, 1995). We found that inhibition of PI 3-kinase signaling by LY294002 blocks the antiapoptotic effect of IGF-I after NGF withdrawal in sensory neurons. In comparison, the MAP-kinase/ERK inhibitor PD98059 had little effect on neuronal apoptosis within this paradigm. We and others previously reported that PI 3-kinase signaling in neuronal and nonneuronal cells is important for IGF-mediated inhibition of PCD from a variety of proapoptotic stimuli including high glucose and hyperosmolarity (Singleton et al., 1996a; Russell et al., 1997; Párrizas et al., 1997; D'Mello et al., 1997; Kulik et al., 1997); in contrast, neurite outgrowth in vitro requires signaling though the MAP-kinase 
pathway (Kim et al., 1997). While our current and past data suggest IGF-I mediates separable signaling pathways effecting cell death, Párrizas et al. (1997) reported an additional role for MAP-kinase/ERK signaling in IGF-I inhibition of apoptosis occurring in PC12 cells after NGF deprivation.

We have previously found that under conditions of hyperglycemic or hyperosmolar stress autophosphorylation of IGF-IR activates PI 3-kinase, which in turn up-regulates protein expression of the PCD inhibitors bcl-2 and bcl-xL (Singleton et al., 1996a; Russell et al., 1997). These proteins determine whether a "death switch" is activated. Once activated, this switch turns on caspase- 8 and other downstream ced-3/interleukin- $\beta$ converting enzyme (ICE)-like proteases, such as caspase-3 (proYama and pro-CPP32) (Chinnaiyan et al., 1996; Singleton et al., 1996a; Russell et al., 1997). In sympathetic neurons, NGF and inhibitors of the ICE-like proteases block apoptosis at a similar time point (Deshmukh et al., 1996). The small, cellpermeable, aspartate-containing "pan-caspase" inhibitor BAF (Deshmukh and Johnson, 1997) has been shown to inhibit cleavage of caspase-3 in vitro. This inhibitor contains sequences corresponding to the aspartate-containing cleavage site of all caspases. We found that BAF was able to almost completely block PCD in DRG neurons after NGF withdrawal, an effect that was maintained for at least $48 \mathrm{~h}$. The degree of PCD inhibition by BAF was similar to that observed with IGF-I alone, and combining IGF-I and BAF did not produce additive inhibition of apoptosis. In agreement with our results, two other peptide inhibitors of ICE, Ac-YVAD$\mathrm{CHO}$ and Ac-YVAD-CMK, are able to block PCD in motor neurons deprived of trophic factors (Deshmukh and Johnson, 1997). Collectively, these results, along with our previous observations on IGFI-mediated inhibition of PCD (Russell et al., 1996, 1997; Singleton et al., 1996a), indicate that IGF-I, like BAF, is able to inhibit activation of the caspase death cascade after NGF withdrawal. However, unlike BAF, IGF-I interrupts cell death signaling well upstream of caspase activation (Russell et al., 1996, 1997; Singleton et al., 1996a).

The distribution of the IGF-I receptor has been previously described both in vivo and in vitro within the mammalian brain (Han et al., 1987) and in avian brain and sensory ganglia (Holzenberger et al., 1997). We found that both human and rat DRG abundantly express IGF-I receptor mRNA throughout the DRG neuronal perikaryon. In vitro, the IGFI receptor was present in rat sensory neurons, and using confocal imaging appeared to be concentrated on the extracellular matrix surface of the growth cone. Our results agree with previous work suggesting the IGF-I receptor is more abundant in neurons than in glia (Burgess et al., 1987) and at growth cones within the brain (Mascotti et al., 1997). The abundance of IGF-I receptor within the growth cone suggests a role for IGF-I in axonal adhesion and structural rearrangement of the cytoskeleton. We recently found that IGF-I promotes remodeling of the actin cytoskeleton and formation of focal adhesions via activation of PI-3 kinase (Leventhal et al., 1997; Leventhal and Feldman, 1997). These data are interesting in light of evidence suggesting an association between PCD, cellular adhesion, and the cytoskeleton (Malorni et al., 1995). Indeed, cells denied anchorage undergo a form of PCD called "anoikis" (Frisch and Francis, 1994). Attachment per se is insufficient to prevent anoikis; what is required is the tyrosine phosphorylation of kinases such as focal adhesion kinase (FAK) involved in cytoskeletal organization (Ruoslahti and Reed, 1994; Topper et al., 1995). Collectively, these findings suggest that the DRG IGF-I receptor may, in addition to its effect on bcl/caspase signaling, prevent PCD by promoting adhesion to the extracellular matrix and stabilization of the actin cytoskeleton.

In summary, the abundance of functional IGF-I receptor both in embryonic DRG and adult human DRG suggests an important role for IGF-I in sensory neurons. IGF-I's primary effect on embryonic DRG sensory neurons is inhibition of PCD after NGF withdrawal. Inhibition of PCD requires IGFI directed signaling through the PI 3-kinase pathway, but not through MAP kinase/ERK. Our results support a role for IGF-I in DRG embryogenesis, and suggest that IGF-I may afford a potential treatment for neurotoxic and traumatic neuropathies.

The authors thank Dr. Brenda Shiver, of Warner-Lambert, Parke-Davis, for providing BAF; Dr. Peter Dyck, of the Mayo Clinic and Foundation, for providing human DRG autopsy tissue; Bruce Donohoe, of University of Michigan Cell Biology Laboratory Core Facility, for assistance with TEM sections; Judy Boldt, for expert secretarial assistance; Jim Beals, for photographic preparation; Dr. David I. Yule and the Michigan Diabetes Research and Training Center, for assistance with confocal microscope imaging; and Louanne Gross, B.A., for assistance with in situ hybridization. This work was supported by the Veterans Administration (JWR), NIH NS01938 (JWR), NIH NS14304 (AJW), NIH NS32843 (ELF), and grants from the Juvenile Diabetes Foundation (ELF) and the American Diabetes Association (ELF). 


\section{REFERENCES}

Bondy, C. A., Werner, H., Roberts, C. T., JR., and LeRoIth, D. (1990). Cellular pattern of insulin-like growth factor-I (IGF-I) and type I IGF receptor gene expression in early organogenesis: comparison with IGF-II gene expression. Mol. Endocrinol. 4:13861398.

Burgess, S. K., Jacobs, S., Cuatrecasas, P., and SahyOun, N. (1987). Characterization of a neuronal subtype of insulin-like growth factor I receptor. J. Biol. Chem. 262:1618-1622.

Chinnaiyan, A. M., Orth, K., O'Rourke, K., Duan, H., PoIrer, G. G., and DiXIT, V. M. (1996). Molecular ordering of the cell death pathway: Bcl-2 and Bcl- $\mathrm{X}_{\mathrm{L}}$ function upstream of the CED-3-like apoptotic proteases. J. Biol. Chem. 271:4573-4576.

Coggeshall, R. E., Pover, C. M., and Fitzgerald, M. (1994). Dorsal root ganglion cell death and surviving cell numbers in relation to the development of sensory innervation in the rat hindlimb. Dev. Brain Res. 82:193-212.

Cohen, P., Ocrant, I., Fielder, P. J., Neely, E. K., Gargosky, S. E., Deal, C. I., Ceda, G. P., Youngman, O., Pham, H., and Lamson, G. (1992). Insulinlike growth factors (IGFs): implications for aging. Psychoneuroendocrinology 17:335-342.

Daughaday, W. H., and Rotwein, Deckwerth, T. L., and Johnson, E. M., JR. (1993). Temporal events associated with programmed cell death (apoptosis) of sympathetic neurons deprived of growth factors. J. Cell Biol. 123:1207-1222.

Deckwerth, T. L., and Johnson, E. M., JR. (1994). Neurites can remain viable after destruction of the neuronal soma by programmed cell death (apoptosis). Dev. Biol. 165:63-72.

Deshmukh, M., and Johnson, E. M., JR. (1997). Programmed cell death in neurons: focus on the pathway of nerve growth factor deprivation-induced death of sympathetic neurons. Mol. Pharmacol. 51:897-906.

Deshmukh, M., Vasilakos, J., Deckwerth, T. L., Lampe, P. A., Shivers, B. D., and Johnson, E. M. J. (1996). Genetic and metabolic status of NGF-deprived sympathetic neurons saved by an inhibitor of ICE family proteases. J. Cell Biol. 135:1341-1354.

D’Mello, S. R., Borodezt, K., and Soltoff, S. P. (1997). Insulin-like growth factor and potassium depolarization maintain neuronal survival by distinct pathways: possible involvement of PI 3-kinase in IGF-1 signaling. J. Neurosci. 17:1548-1560.

Dyck, P. J., Karnes, J. L., O’Brien, P., OKazaki, H., LAIS, A., and Engelstad, J. (1986). The spatial distribution of fiber loss in diabetic polyneuropathy suggests ischemia. Ann. Neurol. 19:440-449.

Edstrom, A., Ekstrom, P. A., and Tonge, D. (1997). Axonal outgrowth and neuronal apoptosis in cultured adult mouse dorsal root ganglion preparations: effects of neurotrophins, of inhibition of neurotrophin actions and of prior axotomy. Neuroscience 75:1165-1174.
EDwARds, S. N., and Tolkovsky, A. M. (1994). Characterization of apoptosis in cultured rat sympathetic neurons after nerve growth factor withdrawal. J. Cell. Biol. 124:537-546.

Frisch, S. M., and Francis, H. (1994). Disruption of epithelial cell-matrix interactions induces apoptosis. J. Cell Biol. 124:619-625.

Gavrieli, Y., Sherman, Y., and Ben-Sasson, S. A. (1993). Identification of programmed cell death in situ via specific labeling of nuclear DNA fragmentation. $J$. Cell Biol. 119:493-501.

Han, V. K. M., D’ERCole, J., and Lund, P. K. (1987). Cellular localization of somatomedin (insulin-like growth factor) messenger RNA in the human fetus. Science 236:193-197.

Holzenberger, M., Lapointe, F., Leibovici, M., and LIEVRE, C. A. (1997). The avian IGF type I receptor: cDNA analysis and in situ hybridization reveal conserved sequence elements and expression patterns relevant for the development of the nervous system. Dev. Brain Res. 97:76-87.

Jones, J. I., and Clemmons, D. R. (1995). Insulin-like growth factors and their binding proteins: biological actions. Endocr. Rev. 16:3-34.

Kerezoudi, E., King, R. H., Muddle, J. R., O’Neill, J. A., and Thomas, P. K. (1995). Influence of age on the late retrograde effects of sciatic nerve section in the rat. J. Anat. 187:27-35.

Kerr, J. F. R., Wyllie, A. H., and Currie, A. R. (1972). Apoptosis: a basic biological phenomenon with wideranging implications in tissue kinetics. $\mathrm{Br}$. J. Cancer 26:239-257.

Kew, J. N. C., and Sofroniew, M. V. (1997). Brainderived neurotrophic factor, acidic and basic fibroblast growth factors, insulin-like growth factor-I, and various antioxidants do not prevent the apoptotic death of developing septal cholinergic neurons following nerve growth factor withdrawal in vitro. Neuroscience 76:809-820.

Kim, B., Leventhal, P. S., Saltiel, A. R., and Feldman, E. L. (1997). Insulin-like growth factor-I-mediated neurite outgrowth in vitro requires MAP kinase activation. J. Biol. Chem. 272:21268-21273.

Kulik, G., KlipPel, A., and Weber, M. J. (1997). Antiapoptotic signalling by the insulin-like growth factor I receptor, phosphatidylinositol 3-kinase, and Akt. Mol. Cell. Biol. 17:1595-1606.

Lenoir, D., and Honegger, P. (1983). Insulin-like growth factor I (IGF I) stimulates DNA synthesis fetal rat brain cell cultures. Dev. Brain Res. 7:205-213.

Leventhal, P. S., and Feldman, E. L. (1997). Insulinlike growth factors as regulators of cell motility: signaling mechanisms. Trends Endocrinol. Metab. 8:1-6.

Leventhal, P. S., Randolph, A. E., Vesbit, T. E., Schenone, A., Windebank, A. J., and Feldman, E. L. (1995). Insulin-like growth factor-II as a paracrine growth factor in human neuroblastoma cells. Exp. Cell Res. 221:179-186. 
Leventhal, P. S., Shelden, E. A., Kim, B., and FeldMAN, E. L. (1997). Tyrosine phosphorylation of paxillin and focal adhesion kinase during insulin-like growth factor-I-stimulated lamellipodial advance. J. Biol. Chem. 272:5214-5218.

LINDSAY, R. M. (1988). Nerve growth factors (NGF, BDNF) enhance axonal regeneration but are not required for survival of adult sensory neurons. J. Neurosci. 8:2394-2405.

Majno, G., and Joris, I. (1995). Apoptosis, oncosis, and necrosis: an overview of cell death. Am. J. Pathol. 146:3-15.

Malorni, W., Rivabene, R., Straface, E., Rainaldi, G., Monti, D., Salvioli, S., Cossarizza, A., and FRANCESCHI, C. (1995). 3-Aminobenzamide protects cells from UV-B-induced apoptosis by acting on cytoskeleton and substrate adhesion. Biochem. Biophys. Res. Commun. 207:715-724.

Mascotti, F., Cáceres, A., Pfenninger, K. H., and Quiroga, S. (1997). Expression and distribution of IGF-1 receptors containing a $\beta$-subunit variant $\left(\beta_{\mathrm{gc}}\right)$ in developing neurons. J. Neurosci. 17:1447-1459.

Matthews, C. C., and Feldman, E. L. (1996). Insulinlike growth factor I rescues SH-SY5Y human neuroblastoma cells from hyperosmotic induced programmed cell death. J. Cell. Physiol. 166:323-331.

Matthews, C. C., Odeh, H., and Feldman, E. L. (1997). Insulin-like growth factor-I is an osmoprotectant in human neuroblastoma cells. Neuroscience 79:525-534.

Miller, T. M., Tansey, M. G., Johnson, E. M., JR., and Creedon, D. J. (1997). Inhibition of phosphatidylinositol 3-kinase activity blocks depolarization- and insulin-like growth factor I-mediated survival of cerebellar granule cells. J. Biol. Chem. 272:9847-9853.

Muller, Y., TAngre, K., and Clos, J. (1997). Autocrine regulation of apoptosis and bcl-2 expression by nerve growth factor in early differentiating cerebellar granule neurons involves low affinity neurotrophin receptor. Neurochem. Int. 31:177-191.

PÁrrizas, M., Saltiel, A. R., and LeRoith, D. (1997). Insulin-like growth factor 1 inhibits apoptosis using the phosphatidylinositol 3 '-kinase and mitogen-activated protein kinase pathways. J. Biol. Chem. 272:154-161.

RAFF, M. C. (1992). Social controls on cell survival and cell death. Nature 356:397-400.

Ruoslahti, E., and Reed, J. C. (1994). Anchorage dependence, integrins, and apoptosis. Cell 77:477-478.

Russell, J. W., and Feldman, E. L. (1996). Insulin-like growth factor-I (IGF-I) protects sensory neurons from glucotoxicity. Ann. Neurol. 40:510 (abstr.).

Russell, J. W., Parekh, A., Singleton, J. R., and FeldMAN, E. L. (1996). Insulin-like growth factor-I (IGFI) modulates programmed cell death pathways in hyperglycemic neurons. Ann. Neurol. 40:954.

Russell, J. W., van Golen, C., Parekh, A., Singleton, J. R., and FELDMAN, E. L. (1997). Insulin-like growth factor I prevents programmed cell death in neurons. Diabetologia 40(Suppl.) : A549.
Russell, J. W., Windebank, A. J., McNiven, M. A., Brat, D. J., and BrimiJoin, W. S. (1995). Effect of cisplatin and ACTH4-9 on neural transport in cisplatin induced neurotoxicity. Brain Res. 676:258-267.

Russell, J. W., Windebank, A. J., and Podratz, J. L. (1994). Role of nerve growth factor in suramin neurotoxicity studied in vitro. Ann. Neurol. 36:221-228.

Sanger, F., Nicklen, S., and Coulson, A. R. (1977). DNA sequencing with chain-terminating inhibitors. Proc. Natl. Acad. Sci. USA 74:5463-5467.

SAsaki, H., Schmelzer, J. D., Zollman, P. J., and Low, P. A. (1997). Neuropathology and blood flow of nerve, spinal roots and dorsal root ganglia in longstanding diabetic rats. Acta Neuropathol. 93:118-128.

Schmitz, G. G., Walter, T., Seibl, R., and Kessler, C. (1991). Nonradioactive labeling of oligonucleotides in vitro with the hapten digoxigenin by tailing with terminal transferase. Anal. Biochem. 192:222-231.

Scott, S. A., and DAviEs, A. M. (1990). Inhibition of protein synthesis prevents cell death in sensory and parasympathetic neurons deprived of neurotrophic factor in vitro. J. Neurobiol. 21:630-638.

Singleton, J. R., Dixit, V. M., and Feldman, E. L. (1996a). Type I insulin-like growth factor receptor activation regulates apoptotic proteins. J. Biol. Chem. 271:31791-31794.

Singleton, J. R., Randolph, A. E., and Feldman, E. L. (1996b). Insulin-like growth factor I receptor prevents apoptosis and enhances neuroblastoma tumorigenesis. Cancer Res. 56:4522-4529.

Sortino, M. A., and CANONico, P. L. (1996). Neuroprotective effect of insulin-like growth factor I in immortalized hypothalamic cells. Endocrinology 137:14181422.

Tong, L. Q., Werrbach-Perez, K., and Perez-Polo, J. R. (1997). Retinoic acid induces apoptosis in PC12 cells independent of neurotrophic factors. J. Neurochem. 68: $1424-1435$.

Topper, L., Hoffstrom, B., Compton, M., Matter, M., and OTEY, C. (1995). The role of pp $125^{\mathrm{FAK}}$ in suppression of apoptosis in fibroblasts. Mol. Biol. Cell 6:384a.

Ullrich, A., Gray, A., Tam, A. W., Yang-Feng, T., Le Bon, T., Kathuria, S., Chen, E., Jacobs, S., FRANCKE, U., RAMACHANDRAN, J., and FuJITA-YAMAGUCHI, Y. (1986). Insulin-like growth factor I receptor primary structure: comparison with insulin receptor suggests structural determinants that define functional specificity. EMBO J. 5:2503-2512.

VAN DeR Pal, R., KoPer, J., VAN Golde, L., and LoPesCARdozo, M. (1988). Effects of insulin and insulinlike growth factor (IGF-I) on oligodendrocyte-enriched glial cultures. J. Neurosci. Res. 19:483-490.

ViAENE, A., and BAERT, J. (1995). In situ hybridization of DIG-labeled RNA probes in a study of cytokeratin expression in human esophageal epithelium. Biochemica 11:20-22.

Werner, H., Woloschak, M., Adamo, M., Shen-Orr, Z., Roberts, C. T., JR., and LeRoITh, D. (1989). De- 
velopmental regulation of the rat insulin-like growth factor I receptor gene. Proc. Natl. Acad. Sci. USA 86: $7451-7455$.

WindeBANK, A. J., and BleXrud, M. D. (1986). Characteristics of neurite outgrowth from rat spinal ganglia: effects of serum and segmental level. J. Neuropathol. Exp. Neurol. 45:683-691.

YAO, R., and COOPER, G. M. (1995). Requirement for phosphatidylinositol-3 kinase in the prevention of apoptosis by nerve growth factor. Science 267:20032006.

Zackenfels, K., Oppenheim, R. W., and Rohrer, H. (1995). Evidence for an important role of IGF-I and IGF-II for the early development of chick sympathetic neurons. Neuron 14:731-741.

ZACKENFEls, K., and RoHrer, H. (1993). IGF-I stimulates chick sympathetic neuron proliferation in vitro and in vivo. Ann. NY Acad. Sci. 692:302-304. 